\title{
A Short visit from Canada to INPA
}

\author{
by PAUl PIRLOT, \\ Professor, Département de Biologie, \\ Université de Montréal, Canada
}

As a teacher of evolutive morphology, mainly interested in the neuro-anatomy of neo-tropical Mammals and Reptiles, I had the privilege of being selected under the Brazilian-Canadian exchange program for 1971, for a shortterm visit to Amazonia.

1. Purpose of my visit. The purpose of my first visit to INPA was mainly to take advantage of the excursions organized by that institution on the Rio Solimões or its tributaries, in order to collect a number of brains of Mammals and Reptiles from the Amazonian habitats. For approval of the plans and encouragements, I am deeply indebted to Dr. P. Almeida MACHADO, Director General.

I was not looking for any particular species, but willing to take material from any form belonging to the Marsupials, Edentates, Rodents, Chiroptera, Primates, Lacertilis and Ophidia. Perfusion of brains with either formalin or Bouin's fixative can be done easily in the field. My goal was then to bring back to my laboratory in Montreal a sample of brains from as many species as I could obtain within a short time. This was to bc achieved in collaboration with INPA parasitologists who are interested in the parasites of the same animals.

2. Summary of my visit. I landed in Manaus early on Thurday, May the 6th, Professor Machado had already arranged forme a trip to Codajas while he himself and Dr. Fonseca were sailing on upstream.

In about 24 hours, we reached Codajas on the 8th of May after a very pleasant jorney indeed, on the ever-fascinating Amazon, on board the "Marupiara". I disembarked there with two field and laboratory assistants, Mr. F.B. de ALMEIDA and Mr. A.F.NETTO. We were accommodated in Palacio Municipal, conveniently located only a few minutes away from the fringe of the forest. With seven traps, four or five cages, nine mistnets, two guns and an inflateble canoe with an outboard motor, we started our collection immediately. Within only fifteen days, we had collected 165 specimens representing some forty species of Vertebrates. I had fixed several dozen brains and $\mathrm{Mr}$. Almeida had examined blood smears from almost all of the animals while Mr. Netto was collecting parasitic worms.

The attention soon frocussed on bats which were practically unknown to my co-workers : trypanosomes and microfilaria were discovered in the blood of several species: I collected the brains of twenty-nine species that I had not possessed before. From a purely quantitative viewpoint, our field work was, therefore, already fully rewarding. I was also especially thrilled to collect a series of five genera of bats that were not yet represented in my material in Montreal, and that I had greatly missed a previousy (i.e. in two papers publis hed on the anatomy of the brain in Chiroptera). Several species of Marsupials and lizards also yielded interesting brains and blood parasites.

We returned to Manaus in one day on Monday, the 24th of May. After this date, I made a small collections of 17 bats in the nearby area. 
3. Facility and difficulty. I would like to stress how pleasant it has been for me to receive all the assistance that I could hop from INPA. Nothing was spared to make my trip fruitful, and I am grateful to everyone. Most important of all, I found understanding at all levels. I was able to discuss my own general interests with several persons working in fields other than mine and that greatly helped me. Much valuable information, which will be used in later studies, has been derived from such friendly talks - especially friendly, if one considers the indulgence with which my hears listen ed patiently to me although my knowledge of Portuguese was almost nil. I have been particularly pleased to receive intelligent and devoted help from the two assistants who accompanied me in Codajas. It is seldom that one finds so much practical scientific knowledge among laboratory technical staff.

The only scientific difficulty that I encountered was identifing the less familiar species of Verterbrates, particularly the Reptiles and Amphibians. Books on this auna are rare. The INPA has started a collection of reprints. It is hoped that this collection will increase rapidly, so that the availability of specialized articles will compensate for the shortage of more general works. Another suggestion, under the circumstances, would be to keep at INPA an alphabetical card-index of all species collected by the INPA staff and researchguests.

As far as laboratory equipment is concerned, I would like to make two suggestions. The first one is to have at INPA two more weighing scales or balances, one to be used in the laboratory, a high precision instrument, and the other one for field-work, a sturdy instrunent, reading only to the nearest $0.05 \mathrm{~g}$. for example. The second suggestion is related to my future need for embedded specimens for electron-microscopy; more and more people and visitors are likely to work with that technique. It would be a good thing if, on request a small but quiet and well-ventilated room could be put at their disposal; the main equipment would consist of a storage cabinet for the Epon kits and chemicals, a small refrigerator, a small but powerful vacuum-over and another conventional oven.

4. Overall judgment on my trip and its consequences. I came to an institution where there is no special section for neuro'ogy or vertebrate ecology, two fields to which my work is related. Stili, I never felt a stranger at INPA. People from both local divisions, i.e. forestry and tropical pathology, shared my interests with me my and I could easiiy share theirs. The manifold aspects of adaptation to the environment both internal and external, which are essential in today's biology were, a subject common to all of us.

By and large, I consider that my collection is excellent, taking into account the limitation of time. It provides me with a neuroanatomical material upon which I sha!l work without much delay: indeed, I have already in mind two subjects for an immediate investigation upon this material in cooperation with two of my graduate students.

The most important thing is that we have "got the ball rolling". I hope it will go a a long way. Our Canada-Brazil collaboration is bound to be to our mutual advantage. My observations can help tropical biologists including pathologists, because of their general ecological bearing. Reciprocally, I hope that a Brazilian colleague or student will join me in the neurological adaptations of Vertebrates. For us, the neotropical fauna comes first in importance in several respects and we would greatly benefit from having on our research team a scientist who would be a resident of Brazil.

In conclusion, although I had to shorten my trip for administrative reasons, I am very satisfied and I certainly plano to return to Manaus (with a solidly established researchbudget) in a not too distant future.

Manaus, June 4th, 1971.

NOTE: The laboratory as suggested by Prof. Piriot is alrealdy available. The editor. 